\title{
THE EFFECT OF INVESTMENT DECISIONS, FUNDING DECISIONS, AND PROFITABILITY ON MANUFACTURING COMPANY VALUE IN INDONESIA STOCK EXCHANGE 2015-2018 PERIOD
}

\author{
Swingly Kellen Sumarau ${ }^{1}$ \\ ${ }^{1}$ Accounting Profession Program, Economics and Business Faculty, Sam Ratulangi University, Jl. Kampus \\ Bahu, Manado, 95115, Indonesia \\ Corresponding e-mail: ssumarauw@gmail.com
}

\begin{abstract}
The main objective of company is maximizing company value or wealth for stockholders. The company also could showing value assets owned by company. More and more high value company then more and more high prosperity received by stockholders. The most determinant factors which indicate affect company value are decision investment, decision funding, and profitability. This study uses secondary data such as financial report that published on the Indonesia Stock Exchange and Central Bank of Indonesia during period of 2015-2018. This study intend quantitative approach and conducts multiple regression. This study composes dependent variable is value company whereas independent variable are investment decision, decision funding, and profitability. Results of this study show that in a manner partial decision investment take effect positive and not significant to value company. Decision investment, decision funding, and profitability in a manner simultaneous take effect significant to value company.
\end{abstract}

Keywords: decision investment, decision funding, profitability, company value

JEL Classification : G11,G32,G19

Article info:

Received 3 July 2019

Revised 18 July 2019

Accepted 26 July 2019

Available online 31 July 2019

\section{INTRODUCTION}

Company value can show the value of assets owned by the company. The higher the value of the company then higher the prosperity received by shareholders. This gives a positive signal to the company because by increasing the prosperity of shareholders then they will continue to invest their capital in the company's activities. Thus, every company must show good performance in order to attract investors to invest their capital into the company. The stock price is an assessment of investors on a company, where stock prices indicate that the company has a good performance or not. Investors can also estimate company by comparing the value of the book with market prices. If the book value of a company is higher than the price of its shares, the company has a cheap stock price that shows the company's performance is not good. On the other hand, if a company has a higher market price than its book value, the company has a good rating from investors and shows the company's performance both from the viewpoint of investors, which in turn increases the company's stock price (Harmono, 2011:50).

Comparison of book value and share price is reflected in the Price to Book Value (PBV) ratio of a company. Company value can be measured by Price to Book Value (PBV) or market/book (M/B) ratio (Brigham, 2010:151). This ratio measures the value given by financial markets to management and company organizations as a growing company. 
Companies that are well looked at by investors are companies with profits and safe cash flows, this can be reflected through Price to Book Value (PBV).

There are several reasons why investors use the price ratio to book value (PBV) in investment analysis: First, book value is relatively stable. For investors who lack confidence in the estimation of cash flow, then the book value is the simplest way to compare it. Second, the existence of accounting practices that are relatively standard among companies causes Price to Book Value (PBV) to be comparable between various companies which ultimately can signal whether the company's value is under or overvaluation (Brigham, 2010:98).

\section{LITERATURE REVIEWS}

In this study the PBV ratio is used as a proxy for value of company. There are several reasons why investors use price ratios to book value (PBV) in investment analysis: First, book value is relatively stable. For investors who lack confidence in the estimation of cash flows, the book is considered the simplest way to compare them. Second, the existence of accounting practices that are relatively standard among companies causes PBV to be comparable between various companies which ultimately can signal whether the company's value is under or overvalued (Brigham, 2010:98). A high PBV will make investors confident of the company's prospects in the future. Therefore, the PBV ratio is very important for investors and potential investors to determine investment decisions.

Investment decision. Investment decisions are the most important decisions of other decisions in relation to increasing company value. The basic investment decision is the decision to allocate funding sources (Syahyunan, 2013:1). Investment decisions made by companies are influenced by the ability of companies to produce cash that can meet longterm and short-term needs or what is called company liquidity. Companies must maintain liquidity so that it is not disrupted, so as not to disrupt the smooth running of the company's activities to invest and not lose the confidence of outsiders (Hidayat, 2010:462). With the above statement, it can be concluded that the investment decision is very influential for the value of the company. In this case the financial manager runs the function of using funds must look for investment alternatives to be analyzed and make investment alternative decisions which one will be chosen. The proxy used to measure investment decisions in this study is Total Asset Growth (Rury, 2012) . Total Asset Growth (TAG) is the growth of company assets from one particular year to the next and shows the magnitude of investment growth in the fixed assets of the company. The results of the right investment decisions will result in optimal performance so that it can increase the growth of the company's assets. Asset Growth is the average growth of corporate wealth. If the initial wealth of a company is still in number, then at a high level of growth of assets it means that the size of the company's final wealth is greater. Likewise, on the contrary, the high growth rate of assets when large high-end wealth means initial wealth is low. The results of the right investment decisions produce optimal performance so that it can increase the growth of company assets (Sumarsono, 2013:39).

Funding decision. Funding decisions are decisions related to determining the sources of funds to be used, determining the optimal funding balance, and companies using sources of funds from within the company or will take funds from outside the company (Kodrat and Christian, 2009:135). Companies must make the most optimal funding decisions so that debt and equity are truly combinations that can generate profits or returns for companies that ultimately maximize the value of the company (Ambarwati, 2010:2). Companies use debt with the aim that the profits obtained are greater than the cost of assets and sources of funds, thereby increasing shareholder profits (Agus, 2010:257). Funding decisions can be measured by Debt to Equity Ratio (DER). DER shows the comparison between debt and equity in 
corporate finance and shows the company's own capital capabilities to fulfill all of its obligations (Sadalia, 2010: 62).

Profitability. Profitability ratios are used to measure a company's ability to generate profits using company-owned resources (Sudana, 2015:25). The profitability used in this study is measured using ROE. ROE is the ability of a company to generate profits after tax using the own model that the company has. This ratio is important for shareholders, for knowing the effectiveness and efficiency of own capital management carried out by financial management (Sudana, 2015:25). This ratio shows the ability of companies in equity capital to generate profits. Return on Equity (ROE) as one of the profitability ratios is a very important indicator for investors. ROE is needed by investors to measure a company's ability to obtain net income related to dividends. The choice of ROE as a proxy for profitability is because in ROE shown, the higher the ROE indicates the more efficient the company uses its own capital to generate investment profits invested in the company (Sudana, 2015:25). The increase in ROE ratio from year to year means that there is an increase in net income of the company concerned. The increase in net profit can be used as an indication that the value of the company also rises because the increase in the net profit of a company in question will lead to stock prices which also means an increase in the value of the company.

\section{RESEARCH METHOD}

\subsection{Data}

This study uses a causal associative design which is to find out relationship and influence between variables with one another (Sugiyono, 2010:11). This study examines the effect of investment decisions, funding decisions, and profitability on the value of manufacturing companies listed on the Indonesia Stock Exchange (IDX) over period of 2015 to 2018 .

\subsection{Sample}

The population in this study were manufacturing companies listed on the Indonesia Stock Exchange for the period 2015-2018 which were 143 companies. The sample technique used in this study is purposive sampling method. Purposive sampling is a technique of determining samples with certain considerations (Sugiyono, 2010:61). Based on the prescribed considerations, the sample will be chosen meet the following criteria: (1) companies listed on the Indonesia Stock Exchange (IDX) which publishes report finance complete in a period of 2015-2018; and (2) companies listed on the Indonesia Stock Exchange in a row 2015-2018 period which is consecutive publish report finance in a manner complete for period year 2015-2018 . Based on the criteria used, the sample in this study is 28 companies listed as company manufacturing. The data collection method used is right in research this is with method studies documentation that is with collect document report finance every company that becomes sample research for the 2015-2019 period obtained through site www.idx.co.id and www.bi.go.id.

\subsection{Method of analysis}

This study refers to quantitative research that uses multiple regression data analysis techniques panel data models. Multiple regression is an analysis of the relationship between one dependent variable with two or more independent variables (Arikunto, 2010:339). The purpose of using this method is to see directly the influence of several independent variables on the dependent variable (Kuncoro, 2009:235). The data obtained are data with panel characteristics and will be processed using Eviews 8 as well as selecting panel data models. According to (Ariefianto, 2012:148) panel data is a structured data of time and cross section. This kind of data is obtained by observing a series of observations of cross sections (between individuals) in a given period. This study also uses the stages of analysis by conducting 
classical assumption tests and hypothesis testing namely simultaneous significance test (f test), partial test ( $\mathrm{t}$ test), determination coefficient $\left(\mathrm{R}^{2}\right)$.

\section{RESULTS AND DISCUSSIONS}

\subsection{Result}

Descriptive statistics provide a description or description of a data seen from the mean, standard deviation, variance, maximum, minimum, sum, range, kurtosis and skewness (Ghozali, 2011:19). In research, the variables used in the calculation of descriptive statistics are Investment Decision (TAG), Funding Decision (DER), Profitability (RO E), and Corporate Value (PBV). Table 1 presents descriptive analysis of this study.

Table 1. Descriptive statistics of the values of PBV, TAG, DER, ROE

\begin{tabular}{lrrrr}
\hline & PBV & TAG & \multicolumn{1}{c}{ DER } & \multicolumn{1}{c}{ ROE } \\
\hline Mean & 0.449176 & 0.226876 & $1,010,446$ & 0.268125 \\
Median & 0.484242 & 0.120000 & 0.700000 & 0.225000 \\
Maximum & $1,798,651$ & $6,690,000$ & $5,200,000$ & $1,360,000$ \\
Minimum & -0.522880 & 0,000100 & 0.180000 & 0.020000 \\
Std. Dev. & 0.505655 & 0.652075 & 0.989035 & 0.212117 \\
Observations & 112 & 112 & 112 & 112 \\
\hline
\end{tabular}

Source: Research Results, 2019 (Data Processed)

Based on Table 1 shows that the amount of data used in this study is 112 samples of data taken from financial statements published by IDX Fact Book manufacturing companies in 2015 to 2018. The details are as follows:

1. The smallest value of price book value (PBV ) is -0.52 ( $\log$ of 0.30$)$ owned by company Taisho Pharmaceutical Indonesia Tbk on in 2016 and the largest (maximum) is 1.79 (Log 62.90) owned by Unilever Indonesia Tbk on 2018. The average PBV of 112 samples is 0 , 44 with standard deviation equal to 0.50 .

2. The smallest value of total minimum Asset Growth (TAG) is 0,000100 owned by Trias Sentosa Tbk on in 2016 and the maximum is 6.69 owned by Astra International Tbk on in 2018. Average TAG of 112 samples is 0,22 with standard deviation amounting to 0.65 .

3. The smallest (minimum) value of Debt To Equity Ratio (DER ) is 0.18 owned by Hanjaya Mandala Sampoerna Tbk on in 2017 and the biggest (maximum) is 5.20 owned by Indal Aluminum Industry Tbk on in 2016. DER average of 112 samples is 1,01 with standard deviation equal to 0.98 .

4. The smallest value of ROE (minimum) is 0.02 owned by Holcim Indonesia Tbk dh Semen Cibinong Tbk on in 2017 and the maximum is 1.36 owned by Unilever Indonesia Tbk on in 2018. Average ROE from 112 samples is 0,26 with standard deviation equal to 0.21 .

\subsection{Discussion}

The multiple regression analysis of panel data is used to determine the effect of the Investment Decision variable (TAG), Funding Decision (DER), Profitability (ROE) on Corporate Value (Price Book Value) in manufacturing companies. The multiple regression test panel data model is conducted to find the relationship between the independent variable and the dependent variable, through the influence of TAG ( $\left.\mathrm{X}_{1}\right), \operatorname{DER}\left(\mathrm{X}_{2}\right)$, and $\operatorname{ROE}\left(\mathrm{X}_{3}\right)$ on PBV (Y). Table 2 presents the regression results. 
Table 2. Multiple Panel Data Regression Testing

Dependent Variable PBV

Method: Pooled EGLS (Cross-section random effect)

Date: 0 4/1 9/19

Time: 02:14

Sample: 20152018

Included observations: 4

The include sections include: 28

Total pool (balanced) observations: 112

Swamy and Arora estimator of component variances

\begin{tabular}{lrrrr}
\hline \multicolumn{1}{c}{ Variable } & \multicolumn{1}{c}{ Coefficient } & \multicolumn{1}{c}{ Std. Error } & \multicolumn{1}{c}{ t-Statistics } & \multicolumn{1}{c}{ Prob. } \\
\hline Constant & 0.076351 & 0.239633 & 0.318615 & 0.7506 \\
TAG & 0.008972 & 0.034445 & 0.260470 & 0.7950 \\
DER & -0.056494 & 0.0527738 & -1.071219 & 0.2865 \\
ROE & 1,148853 & 0.301470 & 3.810834 & 0,0002 \\
\hline
\end{tabular}

Source: Research Results, 2019 (Data processed)

Based on the management of data in Table 2 in the column coefficients, the regression equation model is obtained as follows:

$$
P B V=0.076+0.008 T A G-0.056 D E R+1.148 R O E
$$

Based on the multiple regression equation, the following interpretation of the regression equation model above: (1) value constants amounting to 0.076 meaning if value variable independent worth 0 , then PBV value will be obtained amounting to $7,6 \%$; (2) value the coefficient of TAG $\left(\mathrm{X}_{1}\right)=0.008$ means every addition of TAG by $1 \%$, if other variables are considered constant, then it will increase PBV by 0, $00008 \%$; (3) DER coefficient $\left(\mathrm{X}_{2}\right)=$ 0,056 , meaning every DER addition of $1 \%$, if other variables are considered constant then will reduce PBV by $0,00056 \%$; and (4) coefficient of ROE $\left(\mathrm{X}_{4}\right)=1.148$, meaning every ROE increase of $1 \%$, if other variables are considered constant, then will increase PBV by 0 , $01148 \%$.

\section{CONCLUSION}

Based on results research and discussion that has been stated earlier then conclusion of this study are as follow: (a) in manner investment partial decision take effect positive and not significant to company value. Dividend policy take effect positive and not significant to value company while decision funding take effect negative and not significant to value company and profitability take effect positive and significant to company value; (b) decision investment, decision funding, and profitability in a manner simultaneous take effect significant to value company. This study also suggests that: (1) investors should know about firm profitability, decision investment, and decision funding especially considering to invest in company registered manufacturing on the Indonesia Stock Exchange; and (2) further studies could add external factors to concern condition economy macro as inflation and exchange rate of currency.

\section{REFERENCES}

Agus, S. (2010). Financial Management: Theory and Application, Fourth Edition. Fourth print. Yogyakarta: Bpfe Yogyakarta.

Ajija, SR (2011). Smart Ways to Master Eviews. Jakarta: Salemba Empat.

Ambarwati, S. (2010). advanced financial management, first edition, first print. Yogyakarta: Graha Ilmu. 
Andianto, A. (2012). Analysis of the Effect of Dividend Policy, Debt, Profitability and Investment Decisions on the Value of Manufacturing Companies on the IDX for the Period 2009-2012. Faculty of Economics and Business, DianNuswantoro University, Semarang .

Ariefianto, M. (2012). Econometrics Essence and Application Using Eviews. Jakarta: Erlangga.

Arifah. (2015). The Effect Of Investment Decision, Funding Decision And

Brigham, E. d. (2010). Financial management. Book 2 of the Eighth Edition. Jakarta: Erlangga.

Budiati, S. (2013). Analysis of the Effect of Insider Ownership, Debt Policy and Field, A. (2009). Discopering Statistics Using SPSS, Thrid Edition. . London: Sage.

Ghozali, I. (2011). Application of Multivariate Analysis with the SPSS Program. Semarang: Diponegoro University Publishing Agency.

Harmono. (2011). Balance-Based Financial Scorecard Management (Theoretical Approach, Case and Business Research), Second Print. Jakarta: Bumi Aksara.

Hidayat, R. (2010). Investment Decisions and Financial Constraints: Empirical Studies

Kuncoro, M. (2009). Research Methods for Business and Economics. First Edition. . Jakarta: Erlangga.

Martono. (2010). Financial management. Yogyakarta: Ekonisia.

Murhaidi. (2009). Analysis of the Fundamental Approach Stock. Jakarta: Index.

Sudana. (2015). Corporate Financial Management (Ed.2). Jakarta: Erlangga.

Sugiyono. (2010). Business Research Methods (Ed. 9th). Bandung: CV Alfabeta.

Sumarsono, H. d. (2013). Effect of Funding Decisions, Dividend Policy and Company Growth on Company Values. Journal of Equililibrium, Vol. 10.No01. Pp. 36-46.

Reverence. (2013). Financial Management (Planning, Analysis and Financial Control). Medan: USU.

Tandelilin, E. (2010). Investment Analysis and Portfolio Management (Ed.1). Yogyakarta: BPFE.

Titin, H. (2012). Effect of Dividend Policy, Debt Policy and Profitability on Company Values. Accounting Journal, Padang State University.

Wardjono. (2010). Analysis of Factors Affecting Price to Book Value and Its Implications on Stock Returns. Financial Dynamics and Banking, vol.2 No1.

Martikarini, N. (2010). Effect of Profitability, Debt and Dividend Policies on the Value of Manufacturing Companies Listed on the Indonesia Stock Exchange Period 20092011. Article of Economics Faculty , Accounting Department , Gunadarma University.

Martono. (2010). Financial management. Yogyakarta: Ekonisia.

Murhaidi. (2009). Analysis of the Fundamental Approach Stock. Jakarta: Index. Nani, M. (2013). Effects of Profitability, Debt Policy, and Dividends on the Value of Manufacturing Companies Listed on the Indonesia Stock Exchange Period 20092011. Faculty of Economics, Accounting Department, Gunadarma University 1-13.

Natalia. (2016). Effect of Funding Decisions, Investment Decisions and Dividend Policies on the Value of Manufacturing Companies that Go Public on the Indonesia Stock Exchange Period 2010-2014. Management Journal , 1-17.

Prana, U. (2015). Learn Data with Eviews. Medan: USU Press.

Prasetyo, D. e. (2012). Effect of Investment Decisions and Funding Decisions on Corporate Values (Study of Property and Real Estate Sector Companies Listed on the Stock Exchange in 2009-2011 Period. Journal of Administrative Sciences .

Pratamawati. (2015). Analysis of the Influence of Investment Decisions, Funding Decisions, Dividend Policies and Interest Rates Against Company Values. 